\title{
Isotopic Tracer Studies of Propane Reactions on H-ZSM5 Zeolite
}

\author{
Joseph A. Biscardi and Enrique Iglesia* \\ Department of Chemical Engineering, University of California at Berkeley, Berkeley, California 94720
}

Received: June 4, 1998; In Final Form: August 27, 1998

\begin{abstract}
Reactions of ${ }^{13} \mathrm{C}$-labeled alkanes show that chain growth and cyclization reactions on $\mathrm{H}-\mathrm{ZSM}$ 5 require the initial formation of the corresponding alkene and its extensive participation in rapid oligomerization/ $\beta$-scission reactions before cyclization occurs. The role of alkene intermediates was established by the initial formation of predominantly unlabeled products from mixtures of propene and propane- $2-{ }^{13} \mathrm{C}$ reactants. Aromatic products of propane-2- ${ }^{13} \mathrm{C}$ reactions on $\mathrm{H}-\mathrm{ZSM} 5$ contain similar fractions of ${ }^{13} \mathrm{C}$-atoms and binomial isotopomer distributions. Sequential formation, rapid intramolecular isomerization, and $\beta$-scission reactions of long surface chains must occur during each aromatization turnover in order to form such binomial ${ }^{13} \mathrm{C}$ isotopomer distributions.
\end{abstract}

\section{Introduction}

In contrast with gas-phase pyrolysis pathways, which lead to tars and coke, non-oxidative catalytic reactions of light alkanes on $\mathrm{H}-\mathrm{ZSM} 5$ form $\mathrm{C}_{6}-\mathrm{C}_{9}$ aromatics. The restricted channel environment in ZSM5 ${ }^{1,2}$ and the ability of these catalysts to maintain a high hydrogen surface pressure during alkane reactions ${ }^{3,4}$ inhibit carbon formation and lead to their unique stability at the high temperatures and low $\mathrm{H}_{2}$ concentration required for aromatization of alkanes. Light alkane chain growth pathways on zeolitic acids involve dehydrogenation, dimerization, cyclization, and aromatization steps, which proceed in parallel with acid-catalyzed and thermal cracking steps. ${ }^{5-7}$

Numerous studies have addressed the mechanism of chain growth and cyclization during light alkane reactions with primary emphasis on measuring the effect of catalyst composition on reaction rate and selectivity. ${ }^{5-12}$ Here, we report direct evidence for the mechanistic sequence and for reactive intermediates using ${ }^{13} \mathrm{C}$ isotopic tracer and exchange methods.

\section{Experimental Conditions}

2.1. Catalyst Preparation. $\mathrm{Na}^{+}$ions in $\mathrm{Na}-Z$ ZSM5 (Zeochem) were replaced with $\mathrm{NH}_{4}{ }^{+}$by contacting the zeolite with a solution of $0.67 \mathrm{M} \mathrm{NH}_{4} \mathrm{NO}_{3}$ (Fisher, Certified ACS, $>98.0 \%$ ) at $353 \mathrm{~K}$ for $10 \mathrm{~h}$. Solids were separated from the solution by filtering. The exchange procedure was repeated three times using fresh $\mathrm{NH}_{4} \mathrm{NO}_{3}$ solutions in order to ensure complete exchange of $\mathrm{Na}$ cations (residual $\mathrm{Na}$ content $<0.07 \%$ by elemental analysis). The catalyst samples were then dried in flowing air at $383 \mathrm{~K}$ for $20 \mathrm{~h}$ and calcined in flowing air at $773 \mathrm{~K}$ for $20 \mathrm{~h}$ in order to decompose $\mathrm{NH}_{4}{ }^{+}$to $\mathrm{H}^{+}$, which resulted in the acidic form of the zeolite $(\mathrm{H}-\mathrm{ZSM} 5)$. The elemental composition of all samples was obtained by atomic emission spectroscopy (Galbraith Laboratories). The atomic Si/ Al ratio was $14.5 \pm 0.9$.

2.2. Catalytic Reaction Studies. Kinetic studies on $\mathrm{H}-\mathrm{ZSM} 5$ catalysts were performed in a gradientless recirculating reactor operated in batch mode. Chemical compositions of reaction products were measured as a function of reaction time and

* Corresponding author. Fax: 510-642-4778. E-mail: iglesia@ cchem.berkeley.edu. reactant conversion. The reaction mixture was circulated using a graphite gear micropump $\left(250 \mathrm{~cm}^{3} \mathrm{~min}^{-1}\right.$, Cole-Parmer) that allowed differential reactor operation $(<2 \%$ reactant conversion per pass). All propane reactions were carried out at $773 \mathrm{~K}$.

The chemical composition of reaction mixtures was obtained using capillary column gas chromatography with flame ionization detection (Hewlett-Packard 5890, HP-1 methyl silicone column, $50 \mathrm{~m}, 0.32 \mathrm{~mm}$ diameter, $1.05 \mu \mathrm{m}$ thickness) and electron-impact mass spectrometry (Hewlett-Packard 5972 mass selective detector). ${ }^{13} \mathrm{C}$ isotopomers were calculated from fragmentation patterns using mathematical models that correct for the mass spectral fragmentation and natural isotopic impurities. ${ }^{13}$

Propane (Matheson, chemical purity > 99.5\%), propene (Matheson, chemical purity $>99.0 \%$ ), ethene (Matheson, chemical purity $>99.0 \%$ ), and propane- $2{ }^{13} \mathrm{C}$ (Cambridge Isotopes, chemical purity $>98.0 \%$, isotopic purity $>99.0 \%$ ) were used as reactants without further purification. Helium (Linde, chemical purity $>99.995 \%$ ) and hydrogen (Matheson, chemical purity $>99.5 \%$ ) were purified by passage through oxygen and molecular sieve traps (13X and $5 \mathrm{~A}$ ) at room temperature. Helium was used as an inert diluent in most of the catalytic studies.

Propane conversion turnover rates are reported as the molar rate of propane conversion per g-atom $\mathrm{Al}$ in the catalyst charge. Batch reactor data are shown as product site yields (moles of product g-atom $\mathrm{Al}$ ) or reactant turnovers (moles of $\mathrm{C}_{3} \mathrm{H}_{8}$ converted per g-atom Al) as a function of contact time. The slopes of these plots give propane conversion turnover rates or product site-time yields. Hydrocarbon selectivities are reported on a carbon basis as the percentage of the converted propane that appears as each reaction product. Hydrogen selectivities are reported as the percentage of the hydrogen atoms in the converted propane that appear within a given hydrocarbon product or as $\mathrm{H}_{2}$.

\section{Results and Discussion}

3.1. Catalytic Reactions of Propane on $\mathbf{H}-\mathrm{ZSM5}$. On $\mathrm{H}-\mathrm{ZSM} 5$, the initial products of propane conversion at $773 \mathrm{~K}$ are primarily propene, $\mathrm{H}_{2}$, and equimolar amounts of ethene and methane. Small amounts of ethane and aromatics are also 


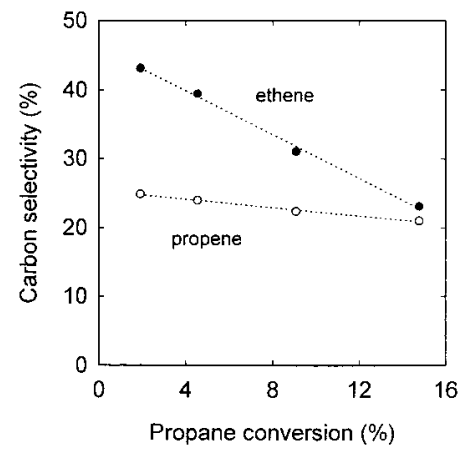

Figure 1. Ethene and propene selectivities during propane conversion on $\mathrm{H}$-ZSM5 (773 K, $\left.26.6 \mathrm{kPa} \mathrm{C}_{3} \mathrm{H}_{8}, 74.7 \mathrm{kPa} \mathrm{He}\right)$.

TABLE 1: Propane Product Distribution on H-ZSM5 (773 $\mathrm{K}$, 26.6 KPa $\mathrm{C}_{3} \mathrm{H}_{8}$, 74.7 $\mathrm{KPa} \mathrm{He}, 24.9 \%$ Propane Conversion, 5.4 ks Contact Time)

\begin{tabular}{lcc}
\hline & $\begin{array}{c}\text { carbon } \\
\text { selectivity }(\%)\end{array}$ & $\begin{array}{c}\text { hydrogen } \\
\text { selectivity }(\%)\end{array}$ \\
\hline methane & 22.4 & 33.6 \\
ethane & 11.8 & 13.3 \\
ethene & 16.8 & 12.6 \\
propene & 15.8 & 11.8 \\
$\mathrm{C}_{4}-\mathrm{C}_{6}$ & 20.4 & 19.2 \\
$\mathrm{C}_{6}{ }^{+}$aromatics & 12.8 & 5.5 \\
benzene & 3.4 & 1.3 \\
toluene & 6.5 & 2.8 \\
$\mathrm{C}_{8}{ }^{+}$ & 2.9 & 1.4 \\
hydrogen $\left(\mathrm{H}_{2}\right)$ & & 4.0
\end{tabular}

formed initially $(<5 \%)$. The initial rate of methane formation $\left(7.7 \times 10^{-4} \mathrm{~s}^{-1}\right)$ is faster than the initial rate of propene formation $\left(3.0 \times 10^{-4} \mathrm{~s}^{-1}\right)$. Ethene and propene are formed with high selectivity at low conversions and decrease with increasing conversion as they are converted to more stable products (e.g. aromatics, alkanes) (Figure 1). Ethene selectivity decreases faster than propene selectivity with increasing conversion. This may suggest that ethene converts to stable products faster than propene on $\mathrm{H}-\mathrm{ZSM} 5$. This is not supported, however, by the individual turnover rates using strictly ethene or propene feeds. On $\mathrm{H}-\mathrm{ZSM} 5$, propene conversion turnover rates $\left(15.0 \times 10^{-4} \mathrm{~s}^{-1}\right)$ are faster than ethene conversion turnover rates $\left(2.4 \times 10^{-4} \mathrm{~s}^{-1}\right)$. The ethene selectivity decreases faster because, at longer contact times, acid-catalyzed alkene oligomerization $/ \beta$-scission reactions control propane conversion selectivity. These oligomerization $/ \beta$-scission reactions are constrained by the zeolite pore structure and by the thermodynamics governing these alkene reactions. On H-ZSM5, Tabak et al. ${ }^{14}$ have shown that alkenes first polymerize on Bronsted acid sites to form dimers and trimers, followed by isomerization, $\beta$-scission, and further oligomerization. Thus, these alkene oligomerization/cracking reactions on Bronsted acid sites lead to a more rapid decrease in ethene selectivity during propane conversion because the formation of ethene, unlike propene, requires unstable primary carbocations.

At low conversions, aromatic products, consisting of a mixture of benzene, toluene, xylenes, and a low concentration of larger aromatics, form slowly. The predominant aromatic product of propane is not benzene, the expected product of $c$ simple dimerization steps, but toluene. Aromatic concentrations increase with conversion because aromatics are secondary products of propane. At higher conversions, reactions of propane on H-ZSM5 lead to aromatics, alkenes, and alkanes with a broad molecular weight distribution (Table 1).

The ratio of 1-butene and isobutene to cis-2-butene and trans2-butene on $\mathrm{H}-\mathrm{ZSM} 5$ instantaneously reaches its equilibrium

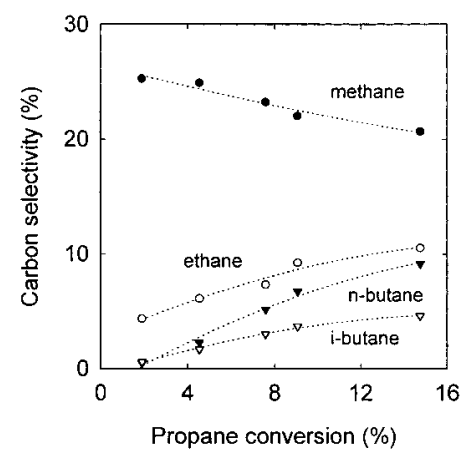

Figure 2. Light alkane selectivities during propane conversion on $\mathrm{H}$-ZSM5 (773 K, $\left.26.6 \mathrm{kPa} \mathrm{C}_{3} \mathrm{H}_{8}, 74.7 \mathrm{kPa} \mathrm{He}\right)$. SCHEME 1: Bimolecular Mechanism Involving Hydride
Transfer to Adsorbed Carbenium Ions

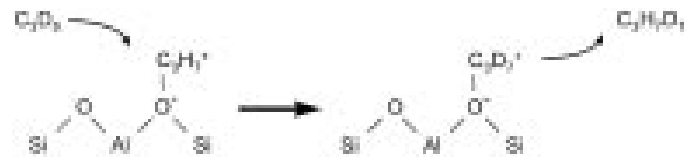

SCHEME 2: Monomolecular Mechanism Involving Alkane Dehydrogenation and Then Adsorption of Alkenes on Bronsted Acid Sites

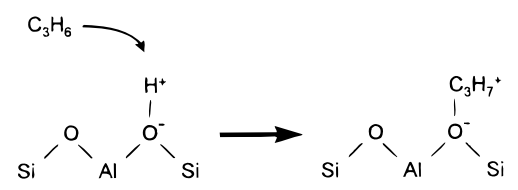

value (1.44). ${ }^{15}$ This indicates that double bond, cis/trans, and skeletal isomerizations occur readily and become quasiequilibrated steps on $\mathrm{H}-\mathrm{ZSM} 5$ even at low conversions. Dihydrogen $\left(\mathrm{H}_{2}\right)$ selectivity remains low and independent of conversion on H-ZSM5 (4.0-6.0\%), while light alkane $\left(\mathrm{C}_{2}\right.$ and $\mathrm{C}_{4}$ ) selectivities increase with increasing propane conversion (Figure 2). Most of the adsorbed hydrogen species formed in dehydrogenation steps appear to transfer to carbonaceous surface species and form $\mathrm{C}_{2}$ or $\mathrm{C}_{4}$ alkanes, rather than recombining and desorbing into the gas phase as $\mathrm{H}_{2}$. The $\mathrm{C}_{2}$ and $\mathrm{C}_{4}$ alkane selectivities increase with increasing conversion because of the higher abundance of hydrogen atoms on the surface as the rate of formation of aromatics increases with increasing contact time.

3.2. Mechanism of Propane Activation Reactions on Bronsted Acid Sites. It has been suggested that carbocations are the reactive surface intermediates in alkane reactions catalyzed by Bronsted acids. ${ }^{16,17}$ However, these surface intermediates may not be true carbocation species, but instead alkoxide species that retain cationic character only in activated complexes during chemical reactions. ${ }^{18-22}$

Mechanistic proposals for light alkane reactions on acid catalysts include hydride transfer from the alkane to an adsorbed carbenium ion (Scheme 1), ${ }^{23-26}$ or protonation of alkenes, formed in preceding dehydrogenation steps to form a carbenium ion (Scheme 2), ${ }^{27-28}$ or direct interaction of the alkane with a proton to form a carbonium ion, followed by $\mathrm{H}_{2}$ desorption to form a carbenium ion (Scheme 3). ${ }^{26}$

The relative contributions of these mechanistic routes in the initial activation of propane on $\mathrm{H}-\mathrm{ZSM} 5$ can be measured using reaction mixtures of propane and propene. Propane- $-2{ }^{13} \mathrm{C}$ $\left.{ }^{12} \mathrm{CH}_{3}-{ }^{13} \mathrm{CH}_{2}-{ }^{12} \mathrm{CH}_{3}\right)$ was used as a reactant to distinguish between the propane fed initially and the propane formed from propene hydrogenation. The propane conversion rates were calculated from those products containing ${ }^{13} \mathrm{C}$, which form only 


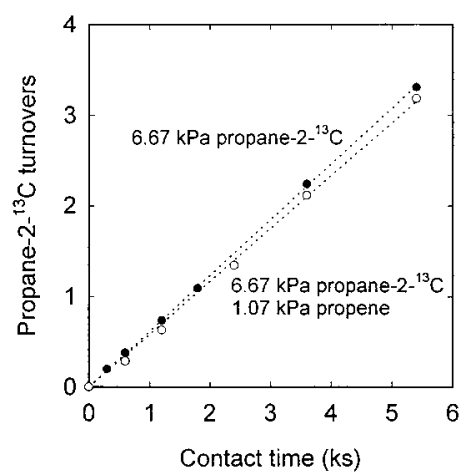

Figure 3. Propane-2-13 $\mathrm{C}$ turnovers versus contact time during propane conversion on $\mathrm{H}-\mathrm{ZSM} 5$ with and without unlabeled propene $(773 \mathrm{~K}$, $6.67 \mathrm{kPa} \mathrm{C}_{3} \mathrm{H}_{8}-2{ }^{13}{ }^{13}, 0-1.07 \mathrm{kPa} \mathrm{C}_{3} \mathrm{H}_{6}$, balance $\mathrm{He}$ ).

\section{SCHEME 3: Monomolecular Mechanism Involving Direct Protonation of the Reacting Alkane}

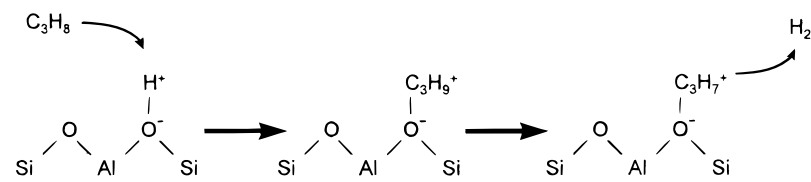

from the propane- $2{ }^{13} \mathrm{C}$ in the feed. This propane/propene reaction mixture allows the measurements of true propane conversion rates during propene addition without contributions by the products of propene reactions. Bimolecular reaction pathways (Scheme 1) would lead to higher propane- $2-{ }^{13} \mathrm{C}$ activation turnover rates when propene is added to the propane${ }_{2-}^{13} \mathrm{C}$ reactants; monomolecular propane activation pathways (Schemes 2 and 3) would be unaffected by the presence of propene.

Turnover rates for propane-2- ${ }^{13} \mathrm{C}$ conversion on $\mathrm{H}-\mathrm{ZSM} 5$ did not increase when unlabeled propene was added (Figure 3 ), suggesting that, at propane partial pressures, propane forms reactive intermediates via monomolecular routes. The propane$2^{-13} \mathrm{C}$ turnover rate on $\mathrm{H}-\mathrm{ZSM} 5$ is $6.1 \times 10^{-4} \mathrm{~s}^{-1}$ with pure propane and only $5.8 \times 10^{-4} \mathrm{~s}^{-1}$ when unlabeled propene is present. These data rule out the possibility that trace amounts of alkenes could significantly influence the rate of propane conversion by providing $\mathrm{C}_{3}{ }^{+}$carbocations that activate propane in hydrogen-transfer bimolecular reactions.

The remaining question is how monomolecular pathways occur: by direct protonation of a propane molecule to form carbonium ions $\left(\mathrm{C}_{3} \mathrm{H}_{9}{ }^{+}\right)$, which then decompose to $\mathrm{C}_{3} \mathrm{H}_{7}{ }^{+}$and $\mathrm{H}_{2}$ (or $\mathrm{C}_{2} \mathrm{H}_{5}{ }^{+}$and $\left.\mathrm{CH}_{4}\right)^{26}$ or by independent dehydrogenation of alkanes on redox sites followed by gas-phase transfer of alkenes to protonic sites where they undergo conventional acid catalysis.. ${ }^{27,28}$ Our studies support the suggestion of propane activation by a monomolecular route, but provide no direct evidence for distinguishing among these mechanisms on H-ZSM5.

3.3. Isotopic Tracer Studies of the Initial Formation of Propene Reactive Intermediates. The initial rate of propane dehydrogenation and the reactive nature of the propene formed were probed by measuring the chemical and isotopic composition of reaction products formed from reactions of unlabeled propene and propane- $2-{ }^{13} \mathrm{C}$. The ${ }^{13} \mathrm{C}$ content in reaction products (extrapolated to zero conversion or contact time) provides a direct measure of the fraction of the products that formed directly from propane without requiring propene intermediates. Isotopic contents in products below that in $\mathrm{C}_{3} \mathrm{H}_{8}-2$ ${ }^{13} \mathrm{C}(0.33)$ would require contributions from unlabeled propene.

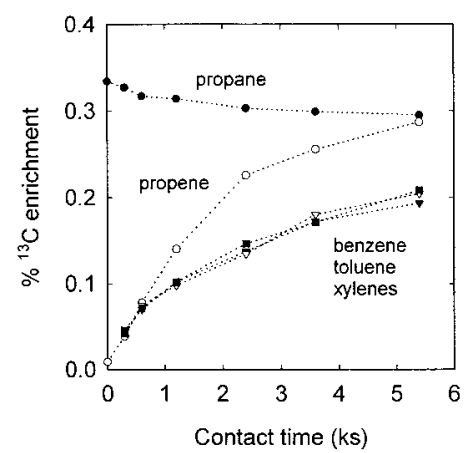

Figure 4. ${ }^{13} \mathrm{C}$ content in propane, propene, benzene, toluene, and xylenes on $\mathrm{H}-\mathrm{ZSM} 5$ using propene/propane- $2{ }^{13} \mathrm{C}$ mixtures $(773 \mathrm{~K}$, $\left.5.6 \mathrm{kPa} \mathrm{C}_{3} \mathrm{H}_{8}-2{ }^{13} \mathrm{C}, 1.1 \mathrm{kPa} \mathrm{C}_{3} \mathrm{H}_{6}, 94.6 \mathrm{kPa} \mathrm{He}\right)$.

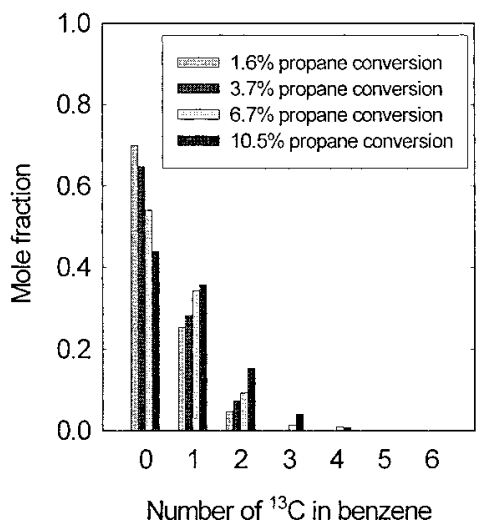

Figure 5. Isotopomer distribution of benzene at different propane conversions ( $\left.773 \mathrm{~K}, 5.6 \mathrm{kPa} \mathrm{C}_{3} \mathrm{H}_{8}-2{ }^{13} \mathrm{C}, 1.1 \mathrm{kPa} \mathrm{C}_{3} \mathrm{H}_{6}, 94.6 \mathrm{kPa} \mathrm{He}\right)$.

TABLE 2: Isotopomer Distribution of Benzene on H-ZSM5 $\left(773 \mathrm{~K}, 5.6 \mathrm{KPa} \mathrm{C} \mathrm{C}_{3} \mathrm{H}_{8-2-}{ }^{13} \mathrm{C}\right.$, 1.1 KPa $\mathrm{C}_{3} \mathrm{H}_{6}, 94.6 \mathrm{KPa} \mathrm{He}$, at 1.6\% Propane Conversion)

\begin{tabular}{ccl}
\hline $\begin{array}{c}\text { no. of }{ }^{13} \mathrm{C} \\
\text { in benzene }\end{array}$ & $\begin{array}{c}\text { mole } \\
\text { fraction }\end{array}$ & \multicolumn{1}{c}{ pathway to benzene } \\
\hline 0 & 0.739 & 2 unlabeled propenes \\
1 & 0.237 & 1 unlabeled propene + 1 labeled propane \\
2 & 0.024 & 2 labeled propanes
\end{tabular}

The initial benzene, toluene, and xylene products on $\mathrm{H}-\mathrm{ZSM} 5$ are predominantly unlabeled, consistent with their direct formation from the unlabeled propene in the feed (Figure 4). The isotopic content in these products increases in parallel with that in propene, because they are formed from increasingly ${ }^{13} \mathrm{C}$ enriched propene. The ${ }^{13} \mathrm{C}$ content in toluene and benzene is slightly lower than in propene because of the fast initial formation of unlabeled larger alkenes, which are diluted slowly with time as the products of the enriched propane reactant begin to contribute to the observed products. The ${ }^{13} \mathrm{C}$ fraction is similar in all aromatic products, suggesting that they all form from a common pool of reactive intermediates derived from similar precursors. Additionally, the fraction of ${ }^{13} \mathrm{C}$ within each of these aromatic products (e.g. benzene) follows a binomial distribution as the reaction proceeds (Figure 5), which indicates that $\mathrm{C}-\mathrm{C}$ bonds are broken and re-formed many times in each precursor species in the time required for the formation of an aromatic molecule. The ${ }^{13} \mathrm{C}$ distribution in the initial benzene product is shown in Table 2 .

At higher conversions (and contact times) the ${ }^{13} \mathrm{C}$ fractions in ethene and butene products are very similar to those in propene (Figure 6). However, the initial ${ }^{13} \mathrm{C}$ content in ethene is higher than in propene, suggesting that some of the ethene forms initially via direct cracking of labeled propane. The initial ${ }^{13} \mathrm{C}$ fraction in ethene suggests that $38 \%$ of the ethene forms 


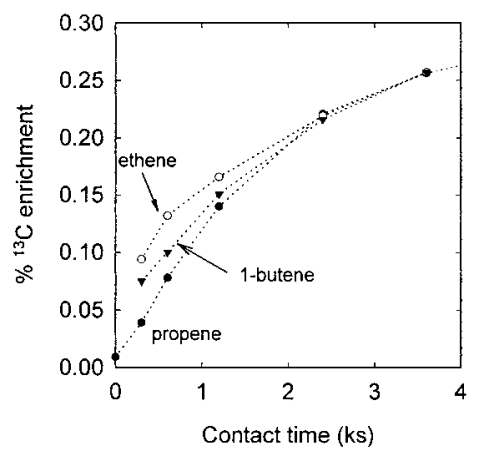

Figure 6. ${ }^{13} \mathrm{C}$ content in reaction products of propene/propane- $-2-{ }^{13} \mathrm{C}$ mixtures on $\mathrm{H}-\mathrm{ZSM} 5\left(773 \mathrm{~K}, 5.6 \mathrm{kPa} \mathrm{C}_{3} \mathrm{H}_{8}-2{ }^{13} \mathrm{C}, 1.1 \mathrm{kPa} \mathrm{C}_{3} \mathrm{H}_{6}, 94.6\right.$ $\mathrm{kPa} \mathrm{He})$.

TABLE 3: ${ }^{13} \mathrm{C}$ Distribution in Ethene on $\mathrm{H}-\mathrm{ZSM} 5$ at $1.6 \%$ Propane Conversion (773 K, 5.6 KPa $\mathrm{C}_{3} \mathrm{H}_{8}-2-{ }^{13} \mathrm{C}, 1.1 \mathrm{KPa}$ $\mathrm{C}_{3} \mathrm{H}_{6}$, 94.6 KPa He)

\begin{tabular}{ccc}
\hline $\begin{array}{c}\text { no. of }{ }^{13} \mathrm{C} \\
\text { in ethene }\end{array}$ & $\begin{array}{c}\text { mole } \\
\text { fraction }\end{array}$ & percent from origin molecule \\
\hline 0 & 0.81 & 61.6\% from unlabeled propene \\
1 & 0.19 & $38.4 \%$ from labeled propane \\
2 & 0.00 &
\end{tabular}

from the direct cracking of labeled propane (Table 3). The initial higher ${ }^{13} \mathrm{C}$ content in butene than in propene shows that butene is formed from both ethene dimerization and from propene via chain growth and subsequent cracking, hence a ${ }^{13} \mathrm{C}$ content between both ${ }^{13} \mathrm{C}$ contents in ethene and propene.

From the initial unlabeled products and the dilution of these products as the reaction proceeds, reactions of propane- $2-{ }^{13} \mathrm{C}$ and propene indicate that propene is a reactive intermediate during propane conversion on $\mathrm{H}-\mathrm{ZSM} 5$. These data give evidence for initial propane dehydrogenation and propane cracking but provide limited information about the chain growth of these alkene intermediates.

3.4. Formation and Scission of Carbon-Carbon Bonds. Reactions of positionally labeled alkanes can be used to study the mechanism of cyclization reactions. ${ }^{29-31}$ Specifically, the analysis of the content and location of ${ }^{13} \mathrm{C}$ in the products of propane- $2-{ }^{13} \mathrm{C}$ reactions can establish the reaction pathways required for the conversion of propene intermediates to stable aromatic products. For example, a simple cyclization of two propene-2- ${ }^{13} \mathrm{C}$ molecules formed from propane- $2-{ }^{13} \mathrm{C}$ would lead to benzene-1,4- ${ }^{13} \mathrm{C}$ in the absence of intramolecular scrambling. In contrast, the formation and expected intramolecular isomerization of large chains as adsorbed alkoxide or cationic intermediates would lead to products with a random number and location of ${ }^{13} \mathrm{C}$-atoms.

Disappointingly, all information about the location and content of ${ }^{13} \mathrm{C}$-atoms in the propane- $2-{ }^{13} \mathrm{C}$ is lost during an aromatization turnover on $\mathrm{H}-\mathrm{ZSM} 5$. Even at low conversion, all aromatic products of propane-2 ${ }^{13} \mathrm{C}$ reactions on $\mathrm{H}-\mathrm{ZSM} 5$ show a binomial distribution of ${ }^{13} \mathrm{C}$-atoms, instead of the single isotopomer expected from propene dimerization and hexene cyclization (Figures 7-9). This binomial isotopomer distribution suggests that propane aromatization on $\mathrm{H}-\mathrm{ZSM} 5$ involves rapid chain lengthening and shortening reactions and intramolecular methyl shifts, which break and re-form every $\mathrm{C}-\mathrm{C}$ bond many times in the time required for an aromatic turnover. Such a turnover requires the formation of $\mathrm{C}_{6}$ or larger molecules, a process that involves oligomerization reactions, but also a significant number of $\beta$-scission and methyl shift events. These oligomerization, $\beta$-scission and isomerization reactions quickly establish an alkene mixture that is independent of the size of

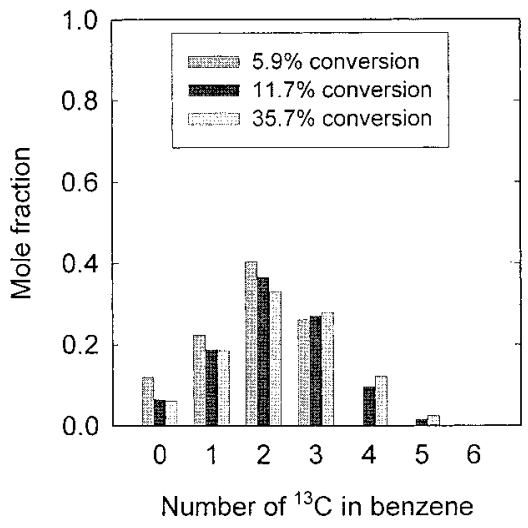

Figure 7. ${ }^{13} \mathrm{C}$ distribution in benzene formed from propane- $2-{ }^{13} \mathrm{C}$ on $\mathrm{H}$-ZSM5 (773 K, $\left.6.7 \mathrm{kPa} \mathrm{C}_{3} \mathrm{H}_{8}-2-{ }^{13} \mathrm{C}, 94.6 \mathrm{kPa} \mathrm{He}\right)$.

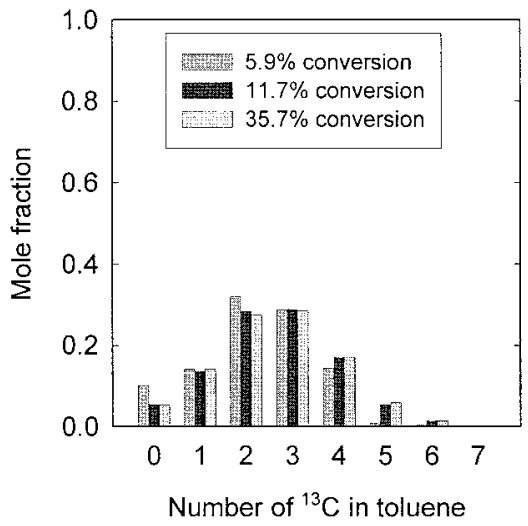

Figure 8. ${ }^{13} \mathrm{C}$ distribution in toluene formed from propane- $2-{ }^{13} \mathrm{C}$ on $\mathrm{H}-\mathrm{ZSM} 5$ (773 K, $\left.6.7 \mathrm{kPa} \mathrm{C} \mathrm{H}_{8}-2-{ }^{13} \mathrm{C}, 94.6 \mathrm{kPa} \mathrm{He}\right)$.

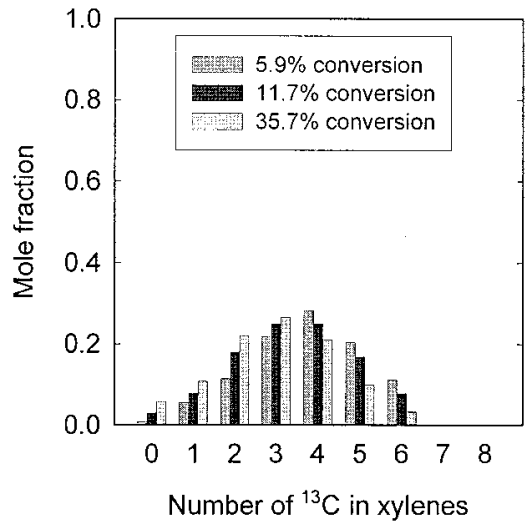

Figure 9. ${ }^{13} \mathrm{C}$ distribution in xylenes formed from propane- $2-{ }^{13} \mathrm{C}$ on $\mathrm{H}$-ZSM5 (773 K, $\left.6.7 \mathrm{kPa} \mathrm{C}_{3} \mathrm{H}_{8}-2-{ }^{13} \mathrm{C}, 94.6 \mathrm{kPa} \mathrm{He}\right)$.

the alkene reactants. ${ }^{32,33}$ Both chain length and methyl group position appear to reach equilibrium values. The broad carbon number distribution within aromatic products of propane reactions on H-ZSM5 (Table 1) is also consistent with extensive $\mathrm{C}-\mathrm{C}$ bond formation and cleavage during aromatization reactions. These fast reactions lead to similar average ${ }^{13} \mathrm{C}$ content and isotopomer distributions in all aromatic products, suggesting that these aromatic products form from a common pool of gasphase and adsorbed alkenes.

The 2-butene product shows a binomial distribution of ${ }^{13} \mathrm{C}$ on $\mathrm{H}-\mathrm{ZSM} 5$ (Figure 10). This distribution suggests that even at very low propane conversion $(<6 \%)$ most of the carbons in 2-butene have undergone extensive $\mathrm{C}-\mathrm{C}$ bond breaking and making during oligomerization/cracking cycles, thus 


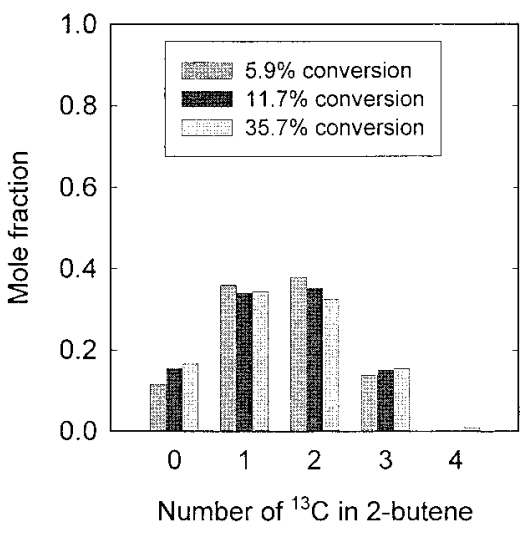

Figure 10. ${ }^{13} \mathrm{C}$ distribution in 2-butene formed from propane-2- ${ }^{13} \mathrm{C}$ on $\mathrm{H}-\mathrm{ZSM} 5\left(773 \mathrm{~K}, 6.7 \mathrm{kPa} \mathrm{C} \mathrm{H}_{8}-2{ }^{13} \mathrm{C}, 94.6 \mathrm{kPa} \mathrm{He}\right)$.

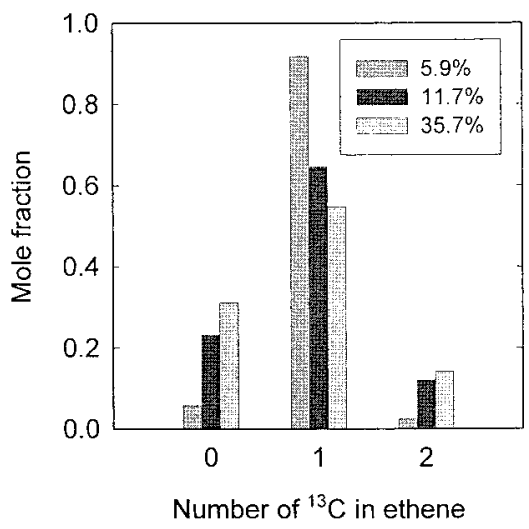

Figure 11. ${ }^{13} \mathrm{C}$ distribution in ethene formed from propane- $2-{ }^{13} \mathrm{C}$ on $\mathrm{H}-$ ZSM5 $\left(773 \mathrm{~K}, 6.7 \mathrm{kPa} \mathrm{C}_{3} \mathrm{H}_{8}-2{ }^{13} \mathrm{C}, 94.6 \mathrm{kPa} \mathrm{He}\right.$, at 5.9, 11.7, and $35.7 \%$ propane conversion).

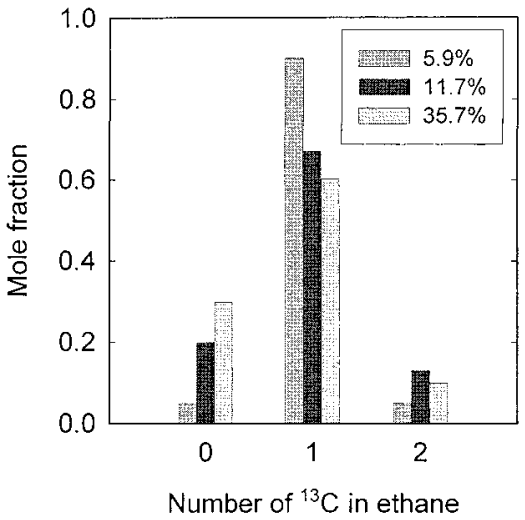

Figure 12. ${ }^{13} \mathrm{C}$ distribution in ethane formed from propane- $2-{ }^{13} \mathrm{C}$ on $\mathrm{H}-\mathrm{ZSM} 5\left(773 \mathrm{~K}, 6.7 \mathrm{kPa} \mathrm{C} \mathrm{H}_{8}-2-{ }^{13} \mathrm{C}, 94.6 \mathrm{kPa} \mathrm{He}\right.$, at 5.9, 11.7, and $35.7 \%$ propane conversion).

producing a nearly binomial 2-butene ${ }^{13} \mathrm{C}$ isotopomer distribution.

At low conversions, ethene and ethane ${ }^{13} \mathrm{C}$ distributions are not binomial and contain mostly one ${ }^{13} \mathrm{C}$ (Figures 11 and 12). Initially, ethene is formed primarily from the direct cracking of propane-2- ${ }^{13} \mathrm{C}$ and not from oligomerization/cracking cycles, which would lead to a binomial ${ }^{13} \mathrm{C}$ distribution in ethene. However, as conversion increases, ethene approaches a binomial ${ }^{13} \mathrm{C}$ distribution, indicating that ethene is mostly formed from alkene cycles that break and re-form $\mathrm{C}-\mathrm{C}$ bonds. Reactions of propane- $2-{ }^{13} \mathrm{C} /$ propene mixtures, described in section 3.3, suggested that only a fraction of the initial ethene product came from direct cracking of propane-2- ${ }^{13} \mathrm{C}$; this discrepancy arose because, with the addition of propene, a higher abundance of

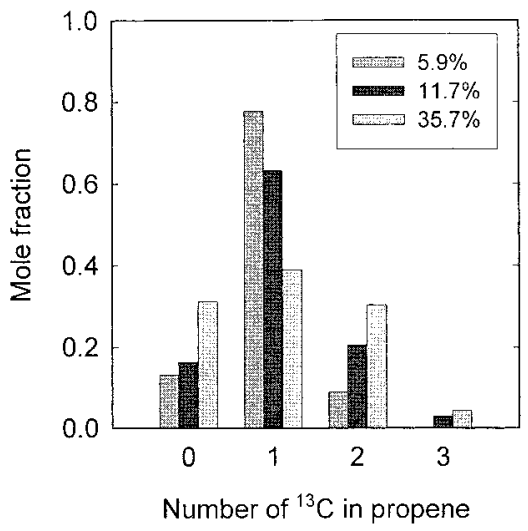

Figure 13. ${ }^{13} \mathrm{C}$ distribution in propene formed from propane- $2-{ }^{13} \mathrm{C}$ on $\mathrm{H}$-ZSM5 $\left(773 \mathrm{~K}, 6.7 \mathrm{kPa} \mathrm{C} \mathrm{H}_{8}-2-{ }^{13} \mathrm{C}, 94.6 \mathrm{kPa} \mathrm{He}\right.$, at 5.9, 11.7, and $35.7 \%$ propane conversion).

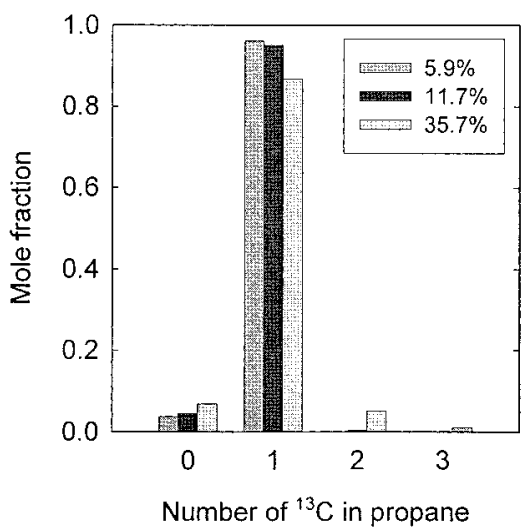

Figure 14. ${ }^{13} \mathrm{C}$ distribution in unreacted propane-2- ${ }^{13} \mathrm{C}$ on $\mathrm{H}-\mathrm{ZSM} 5$ $\left(773 \mathrm{~K}, 6.7 \mathrm{kPa} \mathrm{C}_{3} \mathrm{H}_{8}-2-{ }^{13} \mathrm{C}, 94.6 \mathrm{kPa} \mathrm{He}\right.$, at $5.9,11.7$, and $35.7 \%$ propane conversion).

larger alkenes (from propene) are present at similar propane conversions. These large alkenes crack to dilute the ${ }^{13} \mathrm{C}$-ethene derived from propane-2- ${ }^{13} \mathrm{C}$ cracking, thus lowering the percentage of ethene formed from direct propane cracking at similar propane conversion. The ethene ${ }^{13} \mathrm{C}$ enrichment from Figure 9 , extrapolated to zero contact time, agrees with the fraction of ${ }^{13} \mathrm{C}$ in ethene derived from pure propane-2- ${ }^{13} \mathrm{C}$ feeds.

Similar to the ethene distribution, ethane initially contains mostly one ${ }^{13} \mathrm{C}$ at low conversions (Figure 12). As conversion increases, the ethane isotopic distribution closely resembles that of ethene, suggesting that during propane conversion on $\mathrm{H}-\mathrm{ZSM} 5$, ethane is formed by direct hydrogenation of ethene using $\mathrm{H}$-atoms formed in $\mathrm{C}-\mathrm{H}$ bond activation steps.

The initial propene ${ }^{13} \mathrm{C}$ distribution formed on $\mathrm{H}-\mathrm{ZSM} 5$ is also not binomially distributed and contains mostly one ${ }^{13} \mathrm{C}$ from the direct dehydrogenation of propane- $2-{ }^{13} C$ (Figure 13). As conversion increases, propene begins to acquire a binomial ${ }^{13} \mathrm{C}$ distribution and forms increasingly in alkene cycles. The propane ${ }^{13} \mathrm{C}$ distribution does not change much during reaction, up to about $35 \%$ conversion (Figure 14). It slowly begins to acquire multiple ${ }^{13} \mathrm{C}$ atoms, primarily via hydrogenation of ${ }^{13} \mathrm{C}$ scrambled propene, but, even at $35 \%$ propane conversion, the propane still contains $>87 \%$ of the singly-labeled isotopomer suggesting that propane dehydrogenation/hydrogenation steps are not equilibrated.

3.5. Mechanism of Propane Aromatization on $\mathbf{H}-\mathrm{ZSM5}$ Zeolites. Propane reaction pathways have been extensively discussed in the literature primarily on the basis of observed effects of catalyst composition on reaction rate and selectivity. ${ }^{5-12}$ We have obtained more direct evidence for the sequence of steps 


\section{SCHEME 4. Reaction Network for Propane Conversion on H-ZSM5}

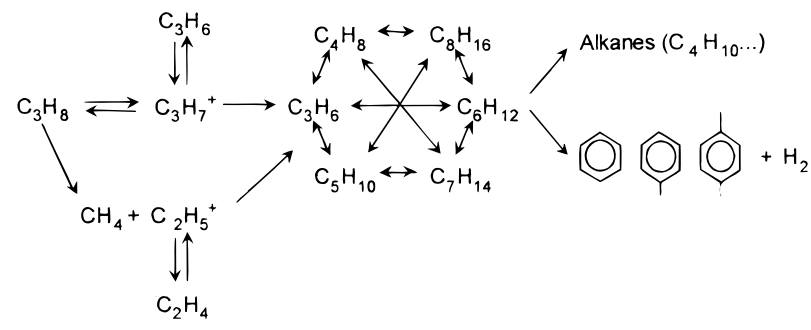

using isotopic tracer and exchange methods. These methods have established the nature of individual reaction steps in this reaction sequence.

The reaction network shown in Scheme 4 is consistent with our results and with previous studies of acid-catalyzed reactions. ${ }^{5,6}$ Propene, initially formed via a dehydrogenation of propane, and ethene, initially formed from propane cracking, undergo rapid acid-catalyzed chain growth reactions within zeolite channels by oligomerization or by addition to $\mathrm{C}_{3}{ }^{+}$ carbocations formed directly from propane. These surface species undergo rapid methyl shift isomerization reactions; as the chain lengthens, $\beta$-scission reactions become faster and ultimately establish a pool of carbocation species and alkene intermediates with a broad size distribution. These alkene intermediates continue to undergo hydrogenation-dehydrogenation reactions, commonly described as hydrogen transfer, in which light alkenes accept hydrogen to form alkanes. $\mathrm{C}_{6}{ }^{+}$ alkenes tend to cyclize and further dehydrogenate to kinetically stable and thermodynamically favored aromatic products. Cracking of larger chains also occurs with the concomitant removal of hydrogen by its addition to light alkene products of cracking reactions. Propane aromatization on $\mathrm{H}-\mathrm{ZSM} 5$ occurs via a complex sequence of dehydrogenation, oligomerization, $\beta$-scission, and cyclization steps (Scheme 4).

\section{Conclusions}

The results from the isotopic ${ }^{13} \mathrm{C}$ labeling studies provide additional evidence for the propane reaction pathways suggested by previous researchers. ${ }^{5-7}$ These isotopic results suggest that propane aromatization occurs on $\mathrm{H}-\mathrm{ZSM} 5$ by a complex reaction sequence, with a first step consisting of propane dehydrogenation to propene or propane cracking to ethene and methane (confirmed by reactions of propene/propane- $2-{ }^{13} \mathrm{C}$ mixtures). Reactions of propane- $2-{ }^{13} C$ show that chain growth on $\mathrm{H}-\mathrm{ZSM} 5$ involves rapid alkene oligomerization/cracking cycles. Stable products, such as aromatics, alkanes, and $\mathrm{H}_{2}$, exit this cycle via cyclization reactions and hydrogen transfer or desorption pathways (Scheme 4). These alkene reactions are necessary to explain the distribution of aromatic products. Products of propane- $2{ }^{13} \mathrm{C}$ reactions on $\mathrm{H}-\mathrm{ZSM} 5$ contain binomial distributions of ${ }^{13} \mathrm{C}$-atoms. Benzene products contain one to five ${ }^{13} \mathrm{C}$-atoms, instead of the two ${ }^{13} \mathrm{C}$-atoms expected from direct propene cyclodimerization. Reactions involve rapid oligomerization/cracking cycles of intermediate alkenes; such reactions break and re-form every $\mathrm{C}-\mathrm{C}$ bond many times during one aromatization turnover. Rapid oligomerization/cracking cycles and intervening methyl shifts lead to the same ${ }^{13} \mathrm{C}$ content and to binomial ${ }^{13} \mathrm{C}$ distributions in all aromatic products.
Along with aromatics, a small amount of hydrogen $\left(\mathrm{H}_{2}\right)$ is also formed as a result of the recombinative desorption of hydrogen adsorbed on the zeolite surface. However, on $\mathrm{H}-\mathrm{ZSM} 5$, the major hydrogen disposal pathway is by hydrogentransfer reactions, which lead to the use of carbonaceous intermediates as stoichiometric sinks for the removal of the hydrogen species formed in sequential dehydrogenation steps.

Acknowledgment. This work was supported by the National Science Foundation (Grant CTS-96-13632) and by University of California startup funds. We acknowledge the technical assistance of Mr. Joseph E. Baumgartner (Exxon Research and Engineering Co.) in the design of the microreactor and in the development of protocols for chemical and isotopic analyses of reaction products.

\section{References and Notes}

(1) Chen, N. Y.; Garwood, W. E. J. Catal. 1978, 52, 453.

(2) Anderson, J. R.; Foger, K.; Mole, T.; Rajadhyaksha, R. A.; Sanders, J. V. J. Catal. 1979, 58, 114. 549 .

(3) Iglesia, E.; Baumgartner, J. E.; Price, G. L. J. Catal. 1992, 134,

(4) Iglesia, E.; Baumgartner, J. E.; Meitzner, G. D. In Proceedings of the 10th International Congress on Catalysis; Guczi, L., Solymosi, F., Tetenyi, P., Eds.; Elsevier: Budapest, 1992.

(5) Guisnet, M.; Gnep, N. S.; Aittaleb, D.; Doyemet, J. Y. Appl. Catal. 1992, 87, 255.

(6) Guisnet, M.; Gnep, N. S.; Alario, F. Appl. Catal. 1992, 89, 1.

(7) Giannetto, G.; Monque, R.; Galiasso, R. Catal. Rev. 1994, 36, 271

(8) Kitagawa, H.; Sendoda, Y.; Ono, Y. J. Catal. 1986, 101, 12.

(9) Yashima, T.; Sasaki, T.; Takahashi, K.; Watanabe, S.; Namba, S. Sekiyu Gakkaishi 1988, 31, 154.

(10) Ono, Y.; Kanae, K. J. Chem. Soc.-Faraday Trans. 1991, 87, 669.

(11) Kwak, B. S.; Sachtler, W. M.; Haag, W. O. J. Catal. 1994, 149 465 .

(12) Engelen, C.; Wolthuizen, J. P.; van Hooff, J. H. Appl. Catal. 1985 , 19,153

(13) Price, G. L.; Iglesia, E. Ind. Eng. Chem. Res. 1989, 28, 839.

(14) Tabak, S. A.; Krambeck, F. J.; Garwood, W. E. AIChe J. 1986, 32,1526 .

(15) Stull, D. R.; Westrum, E. F.; Sinke, G. C. The Chemical Thermodynamics of Organic Compounds; Robert E. Keieger Publishing Co.: Malabar, FL, 1987.

(16) Thomas, C. L. Ind. Eng. Chem. 1949, 41, 2564

(17) Greensfelder, B. S.; Voge, H.; Good, G. M. Ind. Eng. Chem. 1949, $41,2573$.

(18) Kazansky, V. B.; Senchenya, I. N. J. Catal. 1989, 119, 108.

(19) Kazansky, V. B.; Senchenya, I. N. J. Mol. Catal. 1992, 74, 257.

(20) Kazansky, V. B.; Senchenya, I. N.; Frash, M.; van Santen, R. A. Catal. Lett. 1994, 27, 345.

(21) Kazansky, V. B.; Frash, M. V.; van Santen, R. A. Catal. Lett. 1994 $28,211$.

(22) Lercher, J. A.; van Santen, R. A.; Vinek, H. Catal. Lett. 1994, 27, 91

(23) Abbot, J.; Wojciechowski, B. W. Can. J. Chem. Eng. 1985, 63, 462.

(24) Corma, A.; Planelles, J.; Sanchez-Marin, J.; Tomas, F. J. Catal. $1985,93,30$.

(25) Gates, B. C.; Katzer, J. R.; Schuit, G. C. Chemistry of Catalytic Processes; McGraw-Hill: New York, 1979.

(26) Haag, W. O.; Dessau, R. In Proceedings of the 8th International Congress on Catalysis; Dechema: Berlin, 1984; Vol. 305.

(27) Mills, G.; Heinemann, H.; Miliken, T.; Oblad, A. Ind. Eng. Chem. 1953, 45,134

(28) Sommer, J.; Habermacher, D.; Hachoumy, M.; Jost, R.; Reynaud, A. Appl. Catal. 1996, 146, 193.

(29) Iglesia, E.; Baumgartner, J. E.; Price, G. L.; Robbins, J. L.; Rose, K. D. J. Catal. 1990, 125, 95.

(30) Davis, B. H.; Venuto, P. B. J. Org. Chem. 1971, 36, 337.

(31) Price, G. L.; Egedy, G. R. J. Catal. 1983, 84, 461.

(32) Garwood, W. E. Prepr.-Am. Chem. Soc., Div. Pet. Chem. 1982, 27,563 .

(33) Garwood, W. E. ACS Symp. Ser. 1983, 218, 383. 